\title{
Precarious Workers and the Labour Process: Problematising the Core/Non-core
}

\author{
Lynford Dor and Carin Runciman, University of Johannesburg, South Africa
}

\begin{abstract}
This article recentres labour process theory in the analysis of the South African manufacturing sector to challenge the perception that precarious workers in the formal economy are largely "flexible extras" unrelated to the "core" of production. Through case study analysis of two manufacturing workplaces in Gauteng, South Africa, we demonstrate how precarious workers are both core to production and to the production of surplus value. Our analysis demonstrates how employers have increasingly restructured work through reclassifying large parts of the labour process as "non-core". This trend has accelerated in recent years as employers seek to evade new legal responsibilities following amendments to the Labour Relations Act in 2014. Despite employers' attempts to redefine the labour of precarious workers as non-core, we demonstrate that these workers nevertheless play an increasingly central role in the valorisation regimes of manufacturing companies - rendering them core to the production of surplus value for manufacturing capital. Our analysis problematises Von Holdt and Webster's (2005) core/non-core schema for analysing the South African labour force, which locates precarious workers in the formal sector in the non-core. We argue that while this schema has some utility in describing the make-up of the labour force, its abstraction from an analysis of the labour process obscures the fact that precarious work has become central to manufacturing capital's valorisation strategy. Finally, the article reflects on how precarious workers are attempting to organise within and in parallel to trade unions. This analysis highlights the importance of going beyond analysing trade unions if we are to contribute to rebuilding the labour movement under conditions of precarity.
\end{abstract}

\section{KEYWORDS}

Labour-process theory; precarious work; surplus value; labour movement; manufacturing; South Africa

\section{Introduction}

South Africa's reintegration into the global market economy has borne witness to the accelerated use of flexible labour. The use of subcontracted, casualised and other forms of "atypical" employment has overlaid and perpetuated the apartheid system of cheap black labour. Today, it is estimated that four out of ten workers in the formal sector are precarious workers (Webster and Francis, 2018). Such workers, as elsewhere in the world, are especially vulnerable to higher rates of exploitation and earn, on average, half of what a permanent worker earns (Cassim and Casale, 2018).

In South Africa, we argue, the analysis of the growth of precarious labour has largely been abstracted from an understanding of the labour process. Indeed, since the advent of democracy in South Africa in 1994, there has been a shift away from analysing the labour process despite a rich history in this regard (see Sitas, 1983; Webster, 1985; Moodie and Ndatshe, 1994). As a result, 
South African labour studies have tended to understand precarious workers in the formal economy as flexible extras to the labour process, rather than as "core" to production. This article addresses this gap by demonstrating how workers employed under temporary employment services (TES), most commonly called labour broking in South Africa, and other forms of casualised labour are central to manufacturing capital's valorisation model.

The article begins by critiquing the core/non-core schema originally developed by Von Holdt and Webster (2005) and most recently advanced by Webster and Francis (2019) to analyse the South African labour force. While it is a useful descriptive tool to reflect some of the structure of the South African labour market, as an analytical tool it fails to explain how capitalist production has been restructured. By returning to labour process theory (LPT), we argue that the growth in importance of precarious workers in the current period ought not to be established by simply asking if they are "core to production", but, more importantly, by also asking if they are central to the production of surplus value for capital. As such, this article contributes to and builds upon literature that has grappled with the same or similar questions in the context of India (Parry, 2013; Barnes, Lal Das and Pratap, 2015) and extends these discussions into the South African context.

Based on case study research of the labour process in two manufacturing companies in Ekurhuleni, east of Johannesburg, Reckitt Benckiser and PFG Building Glass, we demonstrate capital's willingness to replace their old core permanent workforce with precarious workers wherever possible. The article demonstrates how long-standing trends of casualisation and externalisation deepened following the attempt by the state to regulate the use of TES. In both cases, the manufacturing firms have narrowed the definition of what they consider to be the core work process in order to avoid having to directly employ the majority of the workers in their workplaces. We show how such so-called non-core, externalised workers in fact play a central role in the manufacturing firms' labour processes - not least because the relative proportion of such workers has increased in relation to core workers over the years, rendering their labour increasingly important to the functioning of both factories. The analysis also provides a clearer understanding of where value is produced in the production process and how surplus value is extracted from socalled non-core workers by manufacturing firms.

Capital's ability and desire to restructure the labour process is shaped by the wider political, social and economic context. In this case, amendments to section 198 of the Labour Relations Act (LRA) encouraged employers to find new ways to ensure both the supply of cheap black labour and to break the organising impetus that the new rights gave to workers. The ability of employers to reorganise the labour process has also been assisted by the weakened state of the South African trade union movement, which has largely failed to organise precarious workers. However, this, of course, does not mean that workers do not organise.

The article concludes by reflecting on the experiences of workers organising under conditions of heightened precarity. We highlight the difficulties precarious workers face when the processes of externalisation leave them confronting multiple employers in the same workplace. These struggles, in some cases, are compounded by trade unions that seek to use the numeric majority of precarious workers to further the demands of permanent workers while, ultimately, failing to address the needs and demands of precarious workers (see also Englert and Runciman, 2019). The critique we reveal here is an important counter to what Atzeni (2021:1349) has described as "trade union fetishism", where the locus of attention is placed on trade unions rather than the analysis of actually existing forms of mobilisation. Instead, as Atzeni (2021: 1350) advocates, our aim here is to reflect on "the real processes of struggle and organisation that exist outside/in parallel/around the union form". In doing so we attempt to reflect as accurately as possible the challenges that are facing the broader labour movement inside the industrial workplace at the present conjuncture. 


\section{Analysing Post-apartheid Workplace Restructuring: The Core/Non- core/Periphery Schema}

Following the end of apartheid, labour studies in South Africa grappled with understanding work restructuring through the twin forces of South Africa's reintegration into the global economy and the restructuring of the apartheid workplace (Von Holdt and Webster, 2005). Post-1994 workplaces were now compelled to "redress the apartheid legacy and respond to the demands for a more democratic workplace and society" (Buhlungu and Webster, 2006: 258). At the same time, the global and local forces of capital restructuring had significant consequences in the immediate post-apartheid period. Trade liberalisation devastated many local industries, textiles in particular, and unemployment increased by two million people between 1995 and 2001, creating an unemployment rate of nearly 50 per cent (Gibson, 2006: 2).

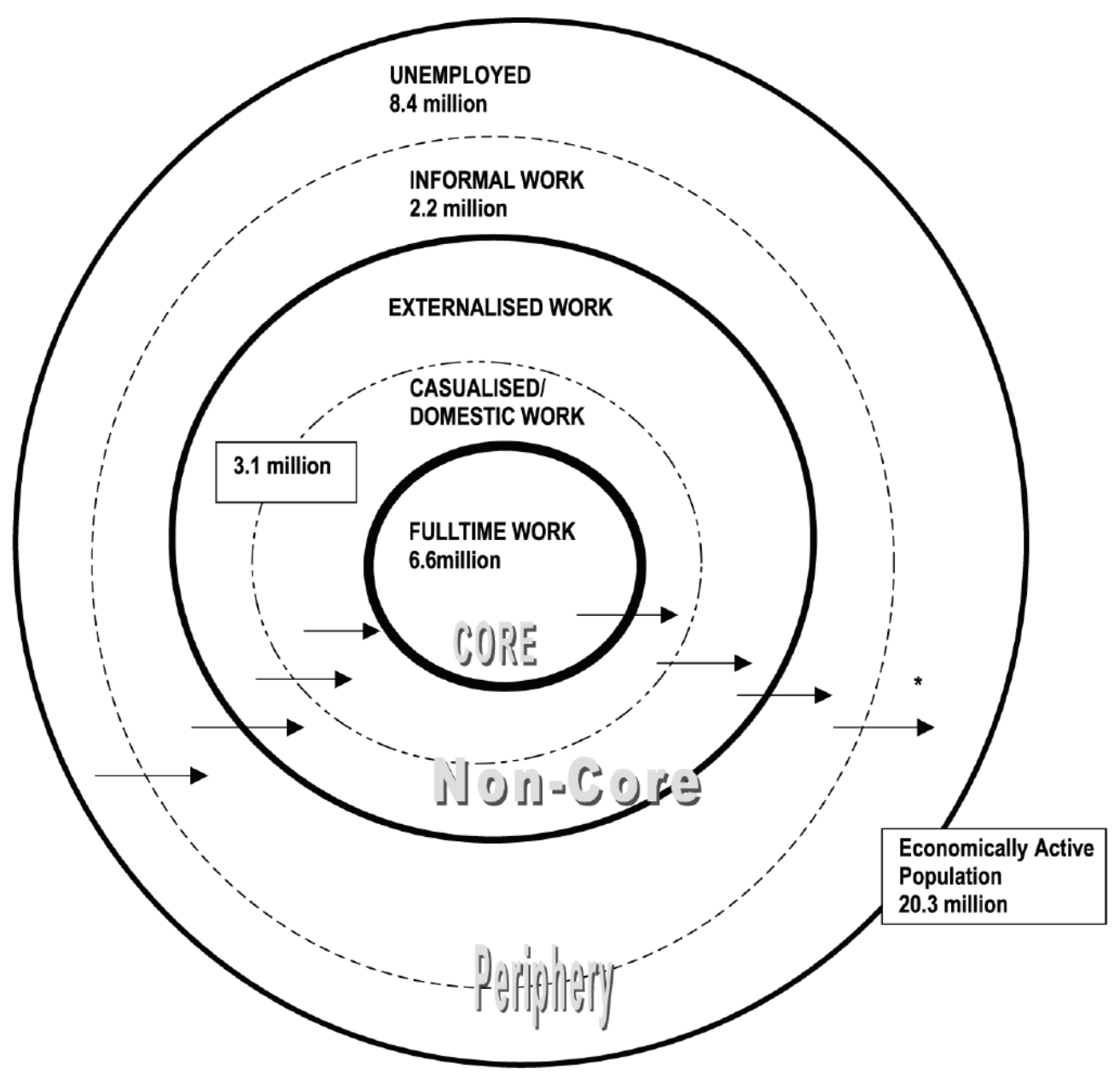

Source: Von Holdt and Webster, 2008: 335

Figure 1. Core, non-core and periphery model

Analysing these macro changes in the immediate post-apartheid period, Von Holdt and Webster $(2005,2008)$ argued that the South African labour force could be disaggregated into three major zones: the core, the non-core and the periphery. Using the image of an onion, they mapped these 
processes into concentric rings with core workers at the centre. The core is defined as being formalsector workers in relatively stable employment with access to benefits and trade unions. The noncore, as a concept, is one which Von Holdt and Webster have refined over time. In its first iteration the non-core is identified as being made up of temporary, part-time, domestic workers and outsourced workers (Von Holdt and Webster, 2005). Developing the concept, Von Holdt and Webster (2008), drawing on the work of Theron (2005), redefine the non-core into two regions of casualisation and externalisation (see Figure 1). Casualisation refers to the process "where workers are engaged directly by core employers, although on terms which are more precarious than those for core workers" (Von Holdt and Webster, 2008: 339), and therefore covers both part-time and temporary work. Externalisation is the process of sub-contracting or employing labour through TES and thus introducing a triangular employment relationship, shielding the real employer from legal obligations to their workers (Dickinson, 2017). These distinctions in the conceptualisation of the non-core are important as they overcome some of the initial problematic framing of non-core workers as having little to no labour rights (see Von Holdt and Webster, 2005: 29). In fact, as the distinction between casualisation and externalisation helps to make clear, all formal sector workers in South Africa, including non-nationals, have, in theory, comparable labour rights and rights to unionise. It is not the lack of formal rights that distinguishes core and non-core workers but their ability to exercise these rights under conditions of precarity.

More recently, Webster and Francis (2019) have collapsed the distinctions between the core and the non-core, and distinguish between the core based on contract type and the non-core defined as having limited or unspecified contracts (see Figure 2). This development is not well explained by Webster and Francis (2019) but would appear to be related to the distinction that the International Labour Organization makes in its definition of formal and informal work related to the presence or absence of a contract (Webster, Britwum and Bhomik, 2017: 8). However, this distinction, is a blunt instrument that does not fully take into account the realities of the contemporary organisation of work in South Africa, highlighting the abstraction of the core/noncore schema from an understanding of the labour process. As we shall demonstrate, permanent contracts of employment are increasingly being offered to casualised and externalised workers as a way to erode conditions of work rather than offer safeguards and security. This is particularly the case for workers employed on zero-hour contracts, a growing trend identified by the Casual Workers Advice Office (CWAO) (see also Webster, 2020).

The strength of the core/non-core model is that it provides a descriptive lens through which to analyse important trends in the labour market. This is particularly welcome considering the limited data that is available to classify and analyse trends in precarious labour (Budlender, 2013; Cassim and Casale, 2018). However, by collapsing the previous distinctions made within the noncore between forces of casualisation and externalisation, Webster and Francis (2019) break down important distinctions that are vital for analysing the restructuring of the labour force, principally the differences between the employment relationships between casualised and externalised workers and the prospects for organising. These distinctions are particularly important in South Africa due to recent changes to labour law affording workers employed under TES greater employment rights, as shall be detailed later. What this critique highlights is the need to revisit the rich history of labour process studies in South Africa in order to better understand the contemporary organisation of work and the prospects for organising. 


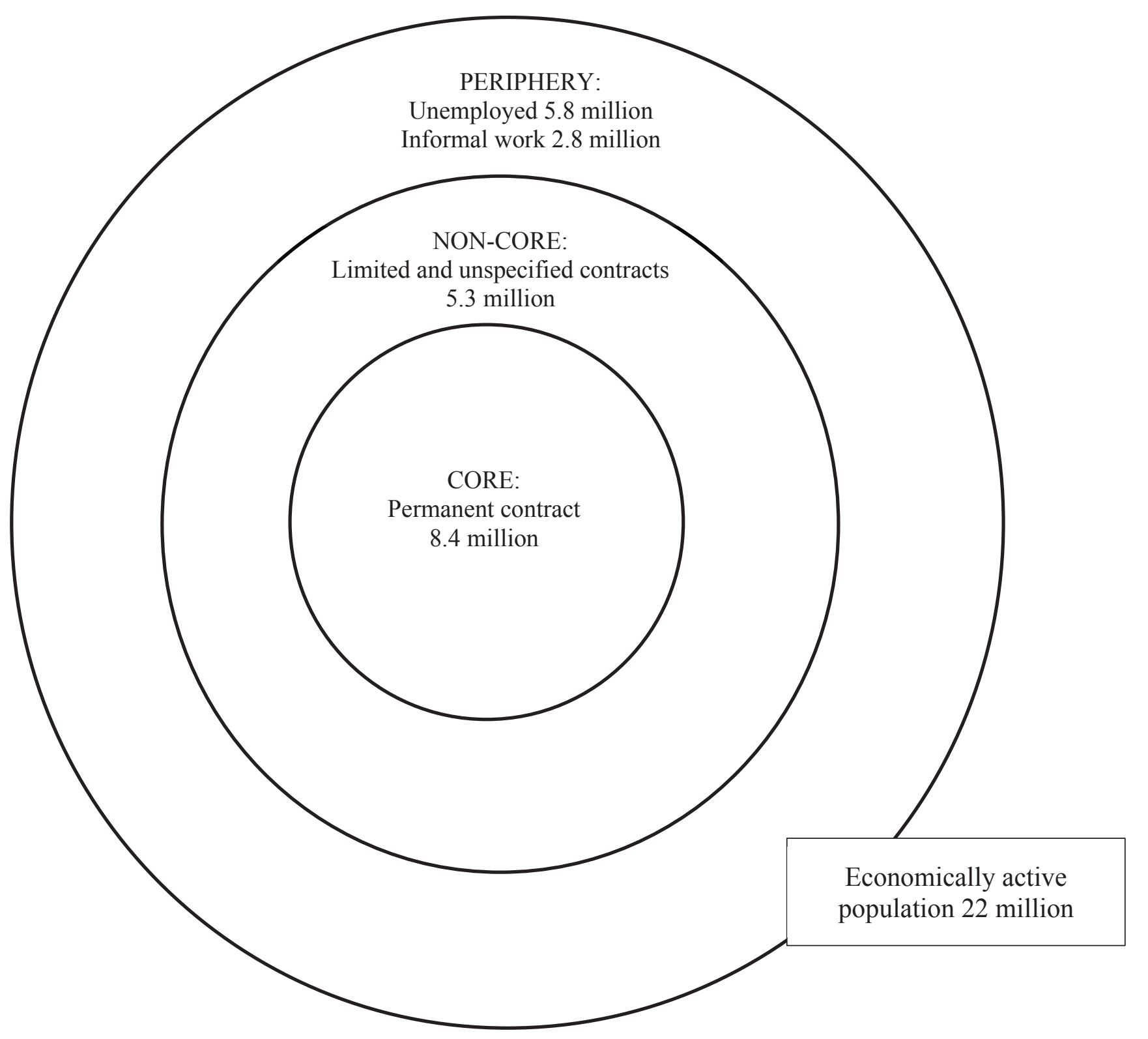

Source: Webster and Francis, 2019: 17

Figure 2. Core, non-core and periphery model

\section{Labour Process Theory and Organising Precarious Labour}

We argue that in order to overcome some of the limitations of the core/non-core schema it is necessary to return to an analysis of the labour process if we are to fully understand the central role that precarious forms of employment play in manufacturing capital's valorisation regime. This then requires us to reconsider the questions associated with organising precarious workers, based on a more accurate understanding of the actual conditions of production that give rise to a reconfigured set of power relations inside the contemporary industrial workplace.

Despite its immediate focus on changes to work processes and advances in machinery, a fundamental concern of LPT is, in fact, the question of power relations in the workplace. Braverman's (1973) Labour and Monopoly Capital sparked renewed interest in the labour process 
among industrial sociologists as well as some Marxists outside of the academy. It built on a central contention of Marx's (1990 [1867]) Capital, which explains transformations in capitalist production in terms of capital's never-ending pursuit of increased rates of surplus value. For both Braverman and Marx, changes in production were driven by capital in its struggle for control over the labour process - that is, its struggle for control over workers and ultimately over the production of surplus value. In the two decades after Braverman (1974) published Labour and Monopoly Capital, there was an explosion of sociological literature on the capitalist labour process - much of which criticised both Braverman and Marx for not paying sufficient attention to the role that worker resistance and consent plays in the structuring of labour processes (Friedman, 1977; Edwards, 1979; Burawoy, 1982; Webster, 1985). Defenders of Braverman and Marx argued that their work did indeed factor in the role of class struggle inside and outside the factory in mediating capital's intended changes to production (Zimbalist, 1979; Wardell, 1990). The benefit of the debate, despite some of its unresolved disagreements, was that it established LPT as a school of study that is concerned with the dialectical relationship between the forces of production and the relations ofproduction. In other words, LPT is interested in how advances in productive technologies (changes in the means of production) and changes to work processes (advances in how labour power is utilised in production) - that is, transformations of capital's productive forces - inform and are informed by a given set of social relations at both a workplace level as well in capitalist society at large.

We argue that an empirical analysis of the manufacturing labour process in the South African context will extend our understanding of how capital has reorganised its productive forces in recent decades and better reveal what capital's current configuration of its production processes means for workplace relations and worker resistance today. As argued in the introduction, much of the impetus for some of the most recent forms of restructuring were in response to amendments to section 198 of the LRA. The following section provides a brief history of the amendment and its implications for workers.

\section{New Rights for Labour Broker Workers}

Despite organising very few atypical workers (Bischoff and Tame, 2017), the Congress of South African Trade Unions (COSATU) has been vocal in its demands to ban labour broking. In response the African National Congress (ANC) government began a process of amending section 198 of the LRA in 2009, to afford labour broker, contract and part-time workers greater rights and protections; this culminated in the 2014 amendment to the LRA. The amendments restrict labour broking to work of a genuinely temporary nature, and requires that labour broker workers become permanent workers of the client company after three months. While this was not a ban on labour broking it was a significant step forward in the rights for labour broker workers. Thousands of workers have since organised to take cases to the Commission for Conciliation, Mediation and Arbitration (CCMA) or the Bargaining Councils in their fight to become permanent. This has largely happened outside of trade unions, either independently or with the assistance of advice offices like the CWAO (Rees, 2019). Employers, of course, have pursued multiple strategies to evade their legal responsibilities either through simply refusing to comply (Webster and Englert, 2020) or through challenging the interpretation of the rules all the way to the Constitutional Court (Constitutional Court, 2018; Smit, 2018). Accelerating forms of externalisation and casualisation have been another strategy. In the following discussion, our case studies illuminate only how externalisation has been used to restructure the labour process. However, the increased use of zerohours contracts, which have been more prevalent in other parts of the world, is another significant form of casualisation that is in need of urgent research and intervention in South Africa today. 


\section{Methodology}

This article presents two case studies from a wider study of workplace restructuring and worker resistance undertaken by Lynford Dor. Individual and group interviews were used and a number of the interviews took the form of mapping the labour process of each company. This method was adapted from other forms of workplace mapping that often focus on power relations within the workplace as a tool for mobilisation (see Brooks, Singh and Winslow, 2017). For our purposes, workplace mapping was used as tool to understand how capital organises the labour power that it buys along the production process. More specifically, it allows us to uncover how management incorporates workers under different forms of employment into the production process, resulting in a clearer appreciation for the specific division of labour found in each workplace. The data generated from these methods was supplemented by knowledge drawn from activist work with the CWAO by both authors. Dor volunteered at the CWAO between January 2017 and December 2019 before taking a permanent position at the organisation as an education officer in January 2020. Runciman has worked as an activist with the CWAO since 2012 and was a management committee member between 2016 and 2021.

The case studies we present are not intended to be generalisable to manufacturing capital across South Africa. Rather, our case studies are intended to demonstrate the analytical limitations of the core/non-core schema and to illustrate how precarious workers are core to the production of surplus value. However, our wider experiences demonstrate that there are grounds to believe that what we present is reflective of wider trends in manufacturing in South Africa, as well as other sectors such as warehousing and logistics (Englert and Runciman, 2019; Dor, 2020).

Unfortunately, our attempts to map the labour process are incomplete (see Figures 3 and 4). This reflects the fragmented nature of the workplaces themselves, where, due to the differing employers and biometric controls, workers are unable to access all areas of the workplace. Shift systems also make it difficult for workers to engage with one another. Furthermore, the acute levels of precarity mean that workers are fearful of being seen to engage with one another across departments in case this leads to dismissals. This meant that we were not able to access workers across all departments and we were reliant upon the knowledge of the key worker activists with whom we engaged. These gaps critically expose the depth of fragmentation in the workplace, and the absence of this knowledge is a significant finding in and of itself.

\section{Precarious Workers and the Labour Process}

The two cases presented here each demonstrate how client companies have managed to circumvent section 198 of the LRA by repackaging labour brokers as "outsourced service providers" (labour broking in disguise) in order to persist with externalisation. This section shows how manufacturing capital has come to rely on the externalisation of its workers - which provides it with more than just cheap labour power but also with qualitatively different forms of control over workers, their organisations and, consequently, over the extraction of surplus value. The presentation of each case is structured broadly around the following themes: (1) management's organisation of the labour process as a result of decades of workplace restructuring, (2) management restructuring in response to the section 198 amendments that were made either pre-emptively or to combat to workers' subsequent struggles for permanent jobs, and (3) an assessment of the overall valorisation regime of the manufacturing firm. In this way, the cases go some way to uncovering how manufacturing firms choose to organise their productive forces in factories today and what this means for workplace relations - that is, relations not just between workers and employers, but also 
relations between different groups of workers. Following this, the next section of the article considers both the prospects and difficulties that workers face in their efforts to organise themselves and build united struggles.

\section{Reckitt Benckiser: A highly fractured labour process}

Reckitt Benckiser is a FTSE 100 British multinational consumer goods company with operations in sixty-four countries employing over 40000 workers across the world (Reckitt Benckiser, 2018). Its factory in Jet Park east of Johannesburg produces well-known household, hygiene and medical products for both the local and international market, such as Cobra floor polish, Jik bleach, Dettol antiseptic, Nugget shoe polish, Blitz firelighters, Gaviscon antacid and a range of aerosols (Eric, interview, 26 August 2019). ${ }^{1}$ The workplace is characterised by the multiple layers of division that management creates between workers through the physical layout of the workplace, the use of multiple different employers from different industries, job grades and shift work. This case demonstrates the extent to which the management of manufacturing companies are willing and able to fracture the labour process to ensure control over it, where externalised workers from a number of subcontracted companies are employed at every level of the labour process and in every job grade.

The workplace is physically divided into different sections, each of which houses the four main functions of receiving, production, warehousing and dispatch. There is also a waste management department and an import/export plant on the premises. Movement around the workplace and between the different functions is highly restricted by the use of a biometric system of fingerprint scanners. Figure 3 depicts Reckitt's organisation of the plant. It demonstrates that across the four separate parts of the workplace, at least seven different companies are involved, excluding the waste management department and the import/export plant.

In receiving, an estimated thirty workers from three labour brokers - Carrus, Transman and Ubuntu - work as clerks, reach truck drivers and forklift drivers alongside a handful of Reckitt's permanents in the same positions. Chemicals and other raw materials are moved from arriving trucks and stored in a small warehouse space between receiving and production. A forklift driver from production then fetches the raw materials to take into the main factory.

In production there are an estimated 200 workers whose labour contributes to the running of fifteen production lines. A minority of these workers are Reckitt's permanents, with the overwhelming majority employed by Carrus, Transman and Ubuntu. For years, the only permanent Reckitt employees in production were a handful of line leaders and supervisors, which are both viewed by workers as management positions (Eric and Siya, interview, 11 June 2019). This finding suggests that capital is not averse to replacing their entire permanent workforce with precarious workers where possible. In other words, there appears to be no inherent limit to the process of "eroding the core" of a company's permanent workforce (Kenny and Webster, 1998).

The warehouse is outsourced to DHL which employs about fifty of its own workers as forklift drivers, packers and sorters. Only one DHL worker interacts with forklift drivers from production in order to do a stock-take of the products handed over. A DHL forklift driver then moves the products into the warehouse where they are prepared for distribution.

Dispatch/Distribution is outsourced by DHL to a company called Vital Distribution Solutions which has no contract with Reckitt itself (see Figure 3 for a graphic representation of this double layer of subcontracting). Vital employs only six of its own workers as supervisors and contracts out the work of loading and driving its trucks to a labour broker called Staffing Solutions,

\footnotetext{
${ }^{1}$ The names of all interviewees have been changed.
} 
who supplies them with around fifty workers. When products are ready for distribution, a DHL forklift driver from the warehouse will offload products at Dispatch for Staffing Solutions workers to load onto the Vital trucks.

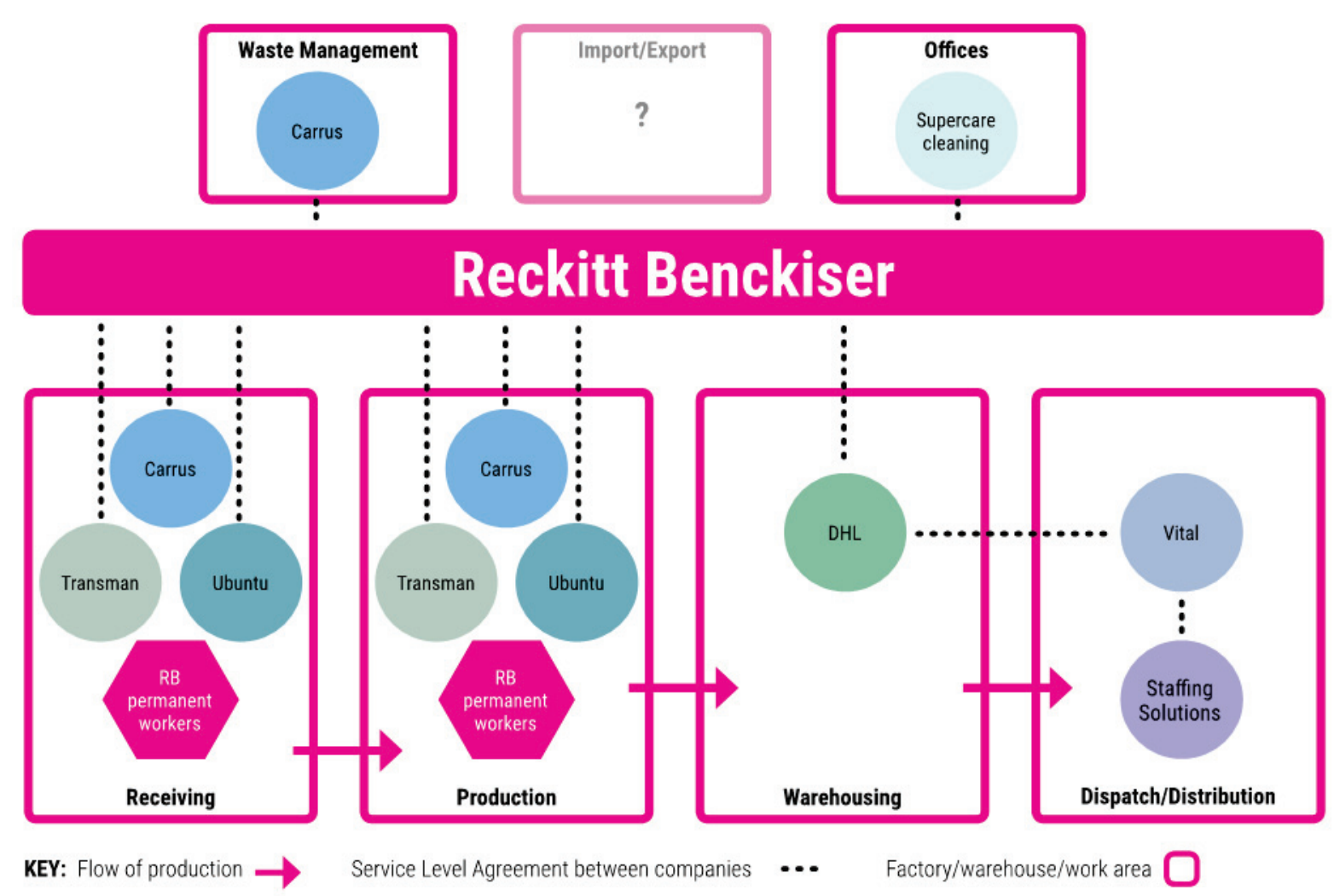

Figure 3. Reckitt Benckiser's labour process

\section{Restructuring at Reckitt post section 198}

After the Constitutional Court (2018) ruled in favour of the "sole employer" interpretation of section 198 of the LRA in July 2018, Reckitt chose to insource only the machine operators who were previously employed by each of the three labour brokers. However, the newly permanent operators still constitute a minority of the workforce inside production, and labour broker workers continue to dominate all areas of the workplace, as shown in Figure 3. This, some workers believe, was a politically motivated insurance measure meant to prevent operators from uniting with the other labour broker workers in a single struggle for permanent jobs. Indeed, it has little to do with an actual reliance on the skills of these workers as one might assume, since, as Eric, who was employed as a general worker, explains that "a week is more than enough to learn to operate ... you just watch while you work and then you can do it" (Eric and Siya, interview, 11 June 2019). Reckitt's valorisation strategy is heavily reliant on securing what Burawoy (1982) would describe as a despotic form of control over its workforce through the use of a number of subcontracted employers.

To prevent workers from claiming permanent jobs under section 198, the labour brokers at Reckitt have remodelled themselves as outsourced service providers - a devious manoeuvre that Carrus somewhat surprisingly explain in detail on their own website: 
We are very confident that the [new] Carrus Business Process Outsourcing (BPO) service offering provides our clients with the ideal alternative to the traditional labour broking solution, whilst retaining the flexibility and cost effectiveness of the aforementioned model. The traditional temporary employment service will remain intact for employment shorter than 3 months and for fixed term contract requirements.

$\mathrm{BPO}$, also known as Functional Outsourcing, is an outsource process (logistics, picking and packing, sales, cleaning, etc.) to a third party which allows the outsource partner to assume the entire labour law risk. This model establishes an 'Arm's Length' relationship between Carrus and the Client, as Carrus assumes de facto control over the outsourced process and provides the Client with labour flexibility within the confines of a service level agreement.

You can basically outsource any process of your choice, i.e. your core business is what you choose it to be (Carrus, 2019: n.p.).

The frank admission that the core business of a client company is what they "choose it to be" supports Englert's (2018) argument that the boundary between a manufacturer's core and noncore functions has become increasingly arbitrary (if not completely meaningless) - especially in a context where the labour movement has been severely weakened, to the point where workers are often unable to effectively resist management restructuring initiatives. Indeed, the claim that labour brokers are actually outsourced service providers of non-core functions has become a primary means by which capital is attempting to circumvent section 198 (Constitutional Court, 2020). Although workers generally reject this unilateral reclassification, as it results in their permanent externalisation, the unfavourable balance of forces at workplace level in the current period means that management is often successful.

What we are now seeing, with examples such as Reckitt, is a move towards the so-called outsourcing of workers who actually contribute to the manufacturing of goods inside the factory so as to avoid having to employ labour broker workers directly as per the requirements of section 198. By reclassifying only machine operating as a core function and all other work in production as non-core, followed by drawing a clear division of labour between permanent workers as machine operators and subcontracted workers in all other positions, Reckitt has attempted to safeguard itself in case workers launch a section 198 case to claim permanent jobs.

\section{Reckitt's overall valorisation model}

Our findings suggest that production work at Reckitt requires a relatively low level of skill as a result of the mechanised nature of the production process, which means that the firm does not need to rely on a large number of permanent, skilled workers and can instead employ cheaper forms of subcontracted labour throughout its factory. In this way, the case shows how changes in productive technologies have over time opened the space for capital to develop and refine different forms of labour control. In other words, changes in the means of production open space for changes in the way capital arranges its labour power along the production process, thus developing its productive forces as a whole. By fracturing its labour process along the lines of its physical layout, the use of multiple different employers from different industries, job grades and shift work, Reckitt is ultimately able to increase the rate at which surplus value is produced in its factory. Externalising the employment relationship, in particular, is central to Reckitt's valorisation model because it provides it with cheap labour and a mechanism to enforce more despotic forms of control over workers in order to keep them divided, keep wages low and increase work speeds (Eric and Siya, interview, 11 June 2019). 


\section{PFG Building Glass: A bifurcated labour process}

PFG Building Glass is a division of the PG Group which was established in Cape Town in 1897. The automation of much of the float glass process means that the majority of work at PFG is conducted by workers away from the production lines in the moving, warehousing and distribution of the glass. This example shows how companies like PFG are able to externalise the most labourintensive elements of the labour process inside their factories as "logistics functions". In doing so, they are able to avoid the ramifications of section 198 in order to keep labour power cheap but also, just as importantly, to maintain control over workers and over the labour process as a whole.

The PFG site in Springs, a small town east of Johannesburg, has two main plants, one which produces building glass and the other automotive glass. There are a few smaller factories on site, as Figure 4 shows. The first cuts glass to specialised sizes on the request of PFG's clients. The second is a glass laminating plant. The third receives different varieties of imported glass from India, China and Argentina and workers then replace any insignia with PFG logos. Finally, there is a glass recycling area which is outsourced to a small company called Thembekile Waste Management (PFG group interview, 14 May 2019; Ryan, 2019). For the purposes of this research, we focused on the larger of the two main plants, which produces large flat sheets of glass for building purposes.

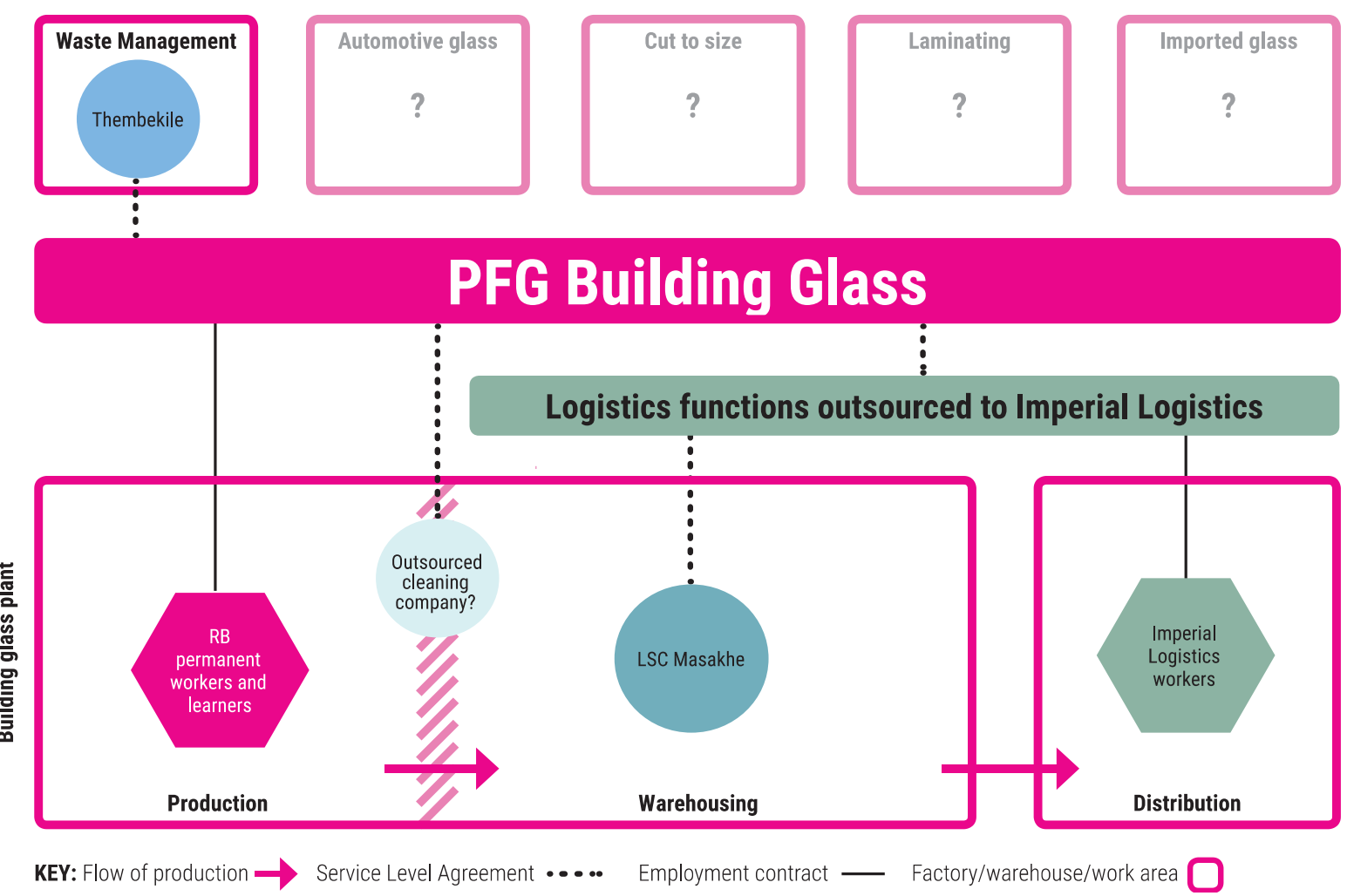

Figure 4. PFG's labour process

The factory houses two highly automated float glass lines. In the receiving phase, suppliers' trucks deliver raw materials that are deposited into large silos (Ryan, 2019). These silos feed the hot end of the lines, where a furnace turns the materials into molten glass which then floats along 
a bed of molten tin. Engineers and specialists are based in a control room while permanent workers are stationed on the hot end of the line in positions of process controllers to monitor chemical and temperature levels. The cold end of the line, where glass is cut and stacked, is operated by ordinary PFG permanent workers. A handful of workers on the cold end are also employed under a learnership programme. The cutting and stacking of glass are automated, which means workers are merely required to monitor the process and reset the stackers if needed.

After the glass is lifted from the line by an automatic stacker and stacked in batches of fifty sheets, it is warehoused and prepared for distribution. This is the most labour-intensive work in the factory and is carried out by hundreds of labour broker workers, working in teams of four: one forklift driver, one crane operator and two handlers. There is no physical division between production and warehousing; they both take place in different halves of the same factory. PFG management, however, treats them as separate functions. Warehousing is outsourced along with distribution as logistics functions to Imperial Logistics. The distribution workers (truck drivers and assistants) are directly employed by Imperial but the workers inside the factory's warehouse are employed under the labour broker LSC Masakhe which is a subsidiary of Imperial. As is the case with almost all labour brokers, LSC now also claims to be a "service provider" to avoid the implications of section 198 (PFG group interview, 14 May 2019).

\section{Restructuring at PFG post section 198}

The division of labour between permanent workers on the production lines and externalised workers in logistics functions was not always so clear-cut. For many years, permanent and labour broker workers worked alongside one another in the same jobs, both on the production line and in the warehouse. In 2015, however, management restructured the plant. Around thirty production line workers that were employed by a labour broker called Capacity were insourced, while all of PFG's permanent workers who had been working in the warehouse were sent to work on the line. Alfred, a worker leader employed by LSC as a crane operator, explained the change quite simply:

Before 2015 we used to work with the permanents. Now they try by all means to keep labour broker workers alone (PFG group interview, 14 May 2019).

Alfred himself started out at PFG under a government-sponsored learnership programme in 2013, which consisted of a five-month theory component focusing on the technical side of glass-making as well as an eight-month stint working on the production line. He eventually took a job as a crane operator under LSC due to the shortage of jobs in production. For the purposes of this research project, his detailed knowledge of both the production and logistics phases of the labour process meant that he was able to act as a key informant.

In hindsight, Alfred and other LSC workers recognised that PFG's reorganisation of work in the factory was linked to the 2015 amendments to section 198 of the LRA (PFG group interview, 14 May 2019). By drawing a clear division of labour between permanents in production and subcontracted precarious workers in logistics, PFG management acted proactively to prevent the latter from claiming their right to permanent jobs. It was not long before LSC workers were told that they were in fact not labour broker workers, but were employed by an "outsourced service provider" (PFG group interview, 14 May 2019).

Despite its supposed outsourcing, logistics work, both inside and outside of the factory, still clearly plays a crucial role in the PFG labour process. In keeping with this, as Alfred explains, PFG management have refused to give Imperial full control of the factory's warehouse: 
Not long ago [in 2019] Imperial asked to be given full management of the warehouse, because PFG make Imperial pay for breakages reported by the clients once the glass is delivered. Imperial say if they had control over the warehouse they can be responsible for breakages, but still PFG want their manager to oversee things in the warehouse (Alfred, interview, 2 April 2019).

What these findings reveal is that the outsourcing of work inside the factory is not a case of PFG management handing over full control of a major part of its labour process to another company. Rather, it is a case of subcontracting to offset risk (Theron, 2005), which simultaneously allows PFG to tighten its control over the entire labour process in the factory. For PFG, the risk associated with the employment contract of the majority of the workers in the plant is offset to LSC Masakhe and Imperial. Just as importantly, so are the health and financial risks associated with the dangerous task of handling and moving huge sheets of glass. On the one hand, PFG retains control over the logistics infrastructure and influences the design of logistics work processes (Alfred, interview, 2 April 2019; PFG, 2019). On the other hand, the production targets established in Service Level Agreements allow it to pass on the burden of enforcing a regime of high work intensity under dangerous working conditions to its subcontractors. Alfred explains how the burden is then transferred onto LSC workers themselves:

\begin{abstract}
Sometimes if the crane fails, if there is a problem with the hydraulics, it [the batch of fifty sheets of glass] will come down, and you will die. The company took all its workers to the line, where it is safe. There you just sit on the chair and the [stacking] machine does the job. Where there is difficulty, where it's dangerous, they put labour broker workers. You can get hurt, they don't care. They will tell you that your safety is in your hands. If anything happens, they get their lawyer to say you were negligent.... They removed those cranes that you sit in because they said they were too expensive (Alfred, interview, 2 April 2019).
\end{abstract}

Alfred's comments offer interesting insights into the logic behind PFG's anxiety to ensure that workers in the warehouse remain externalised. He notes that, due to the high level of automation, work in production is routine and safe while the line speed determines its intensity. In contrast, work in logistics is dangerous and physically taxing, which requires more direct methods of control to ensure that production targets are met. The workers that we interviewed who performed these tasks earned below R5 000 per month and worked twelve-hour shifts (PFG group interview, 14 May 2019). This regime of low wages, long work hours and high work intensity under dangerous working conditions is ultimately achieved through the imposition of third-party employers, which constitutes an attempt to ensure that workers remain politically weak and unable to direct their frustrations at PFG itself.

\title{
PFG's overall valorisation model
}

The automation of production line work means that the more labour-intensive work processes elsewhere in the factory have taken on greater relative importance in the full functioning of PFG's labour process. Workers in "logistics" might not make the glass, but their labour has clearly become central to the task of producing a saleable commodity. Not only does their labour produce new value in the labour process, it also contributes to the realisation of the old value that is transferred into the product by the raw materials and machinery. PFG's valorisation model relies heavily on hi-tech machinery (means of production) but also on its ability to keep down the wages and increase the productivity of the so-called logistics workers - that is, by keeping the value of its labour power low while extracting as much real labour from it as possible. It achieves this primarily by ensuring that their employment remains externalised. Below we see how this particular arrangement of its 
productive forces contributes to a complex set of workplace relations and the fragmentation of associational power.

\section{Fragmented Worker Struggles at Reckitt}

As discussed above, at least seven different companies operate at Reckitt. The warehouse and dispatch functions have been outsourced to DHL and Vital, respectively. Receiving and production use three different TES companies alongside permanent workers employed directly by Reckitt (see Figure 3). This complex web of externalisation and casualisation plays an important role in shaping worker identities and collective struggles. In Dispatch, truck drivers who work for Staffing Solutions, the TES used by Vital, the company to whom Reckitt outsources the dispatch function, have been waging a struggle to be made permanent under Vital. While this demand is understandable in the context of a heavily externalised and casualised workplace, Eric recognises the impact this has on the ability of workers to forge collective struggles:

The workers of Staffing [Solutions] say they want their jobs under Vital. They say, 'We don't know Reckitt, we don't know DHL'. It's not good politically because they can't unite with the rest of the workers in the factory (Eric, interview, 26 August 2019).

What Eric highlights here is that workers in the outsourced section of the plant are unable to identify Reckitt as a target of their demands. As Eric says, "We don't know Reckitt". This means that worker struggles are fragmented into making demands on the different outsourced and TES companies within the workplace. This has resulted in recurring cycles of organising initiatives emerging from different groups of workers in different parts of the plant waged independently of one another.

One of the functions of the forces of externalisation and casualisation seen within Reckitt is that there is no properly functioning union. In 2012 the General Industries Workers Union of South Africa (GIWUSA) was organising labour broker workers inside production, resulting in a strike. However, the strike resulted in most of the workers being dismissed and had a detrimental effect on organising within the plant, as Eric explains:

When GIWUSA workers went on strike in 2012 most of them were dismissed. They were labour broker workers. After that, it [GIWUSA] was there but it was not visible any more. Maybe it was less than ten workers left in the union. They were using it like legal aid (Eric and Siya, interview, 11 June 2019).

For Eric the defeat of the strike meant that the workers that remained had lost faith in the union as a weapon of collective struggle and instead used it merely for representation in individual cases. The long-term ramifications of the strike also meant that the new labour broker workers hired to replace those that were dismissed feared that they, too, would lose their jobs should they attempt to unionise. Since then workers in Dispatch have turned to multiple organising initiatives simultaneously. This has included joining the South African Federation of Trade Unions (SAFTU) affiliated union the National Transport Movement as well as the CWAO. That the workers have both joined a union and turned to the CWAO for help parallels the experiences of precarious workers, who often turn to multiple organisations for assistance (Englert and Runciman, 2019). 


\section{Divided Worker Struggles at PFG}

Permanent workers who work in production at PFG were previously organised by the Chemical, Energy, Paper, Printing, Wood and Allied Workers' Union (CEPPWAWU). At the time CEPPWAWU organised the permanents, Alfred says "they never met with the workers, they just came to meetings with management" and they never attempted to organise workers outside of the permanent workers (Alfred, interview, 2 April 2019). What is more, LSC Masakhe told labour broker workers that they were not allowed to join the union:

The management for Masakhe said that on PFG premises agents [labour brokers] are not allowed to have a union. In such a way that you must be a slave. By then people didn't know about their rights (PFG group interview, 14 May 2019).

By 2015 permanent workers were National Union of Metalworkers South Africa (NUMSA) members; they approached the labour broker workers to join the union, and many labour broker workers did join NUMSA. However, NUMSA did not organise the workers in a common struggle but rather ran meetings with two agendas, one for permanents and one for LSC workers. This follows a similar pattern seen in other workplaces, where even when unions do attempt to organise precarious workers they often entrench the divisions of neo-liberal restructuring in their approach to organising (Englert and Runciman, 2019).

So we realised that there was no need to be in those meetings because the things that we want are not the same. We've only had three mass meeting since 2015. But since then we meet separately. Our needs are not the same so we can't meet together ... On the noticeboard now they [shop stewards and union officials] announce meetings for either permanents only or LSC only. The union is divided (PFG group interview, 14 May 2019).

By treating the demands of labour broker workers and permanent workers separately, the division between the workers is heightened rather than overcome. This is significant because it suggests that although unions like NUMSA, which have at least shown a willingness to recruit precarious workers (Englert and Runciman, 2019), have not been able to develop appropriate strategies to organise them together with permanent workers. It is also indicative of the size of the task facing the labour movement in healing the shop-floor divisions caused by the neo-liberal restructuring of the labour process.

While NUMSA members, the LSC workers began to organise themselves, resulting in an unprotected strike in November 2017 to demand permanent jobs and equalisation in pay, two years after joining NUMSA. As LSC workers demonstrated outside the factory on the first morning, NUMSA officials arrived to tell them that due process had not been followed to gain protection for the strike, as Tebogo explains:

The RS [NUMSA's Regional Secretary] came to tell us that we are not supposed to strike, to go back to work. Around 12 o'clock the union shut the strike (PFG group interview, 14 May 2019).

As Tebogo's words above indicate, while the union official was correct to warn the workers about the prospect of them being dismissed for embarking on an unprotected strike, by "shutting" the strike the union acted in the interests of management and not workers, in their eyes. This began to sow seeds of doubt in the minds of the workers as to whose side the union was on.

By 2018, and without any further progress in winning their demands, LSC workers became 
further suspicious of NUMSA's intentions:

They [NUMSA] said, 'You guys, if you join, we will fight to get you a permanent job'. We didn't know then that these guys were looking to reach the number [of workers that PFG] wanted for recognition [of the union]. Then they came with this trick to say that our issue is difficult because we are called service providers ... They keep saying, 'We will come to your issues'. Meanwhile the permanents keep on buying cars (PFG group interview, 14 May 2019).

What is illustrated here is the concern that NUMSA's primary interest in organising them was not so they would become permanent workers but rather that NUMSA would reach the threshold for representativity by organising them, thus providing them with better prospects in collective bargaining and various organisational rights contained in sections 11 to 22 of the LRA. However, as highlighted above, labour broker workers have not benefitted from NUMSA's improved bargaining power as their demands remain unaddressed while permanents "keep on buying cars". This has led to frustration and suspicion of NUMSA's role in representing their demands with management. Some workers fear that union representatives and shop stewards have been bought off by management to stop them from ever becoming permanent workers. These suspicions, whether true or not, reveal the depth of the divide that exists between different groups of workers and between workers and the union.

The strategic importance of the LSC workers in furthering the demands of permanent workers was underscored further when the PFG permanent workers decided to embark on a strike in April 2018. While the strike confirmed the suspicion of workers that the union saw their role to support the struggle of permanent workers, the strike also served to strengthen their belief in the weight of their own bargaining power in the factory. In a meeting with CWAO organisers in early 2019, Tebogo made this point emphatically:

We are working on Logistics. If the permanent workers from the lines go out to toyi-toyi ${ }^{2}$ and leave us behind it means the glass will continue to be delivered to the customers. We work in logistics and distribution ... the most important part of PFG (PFG worker meeting with CWAO, 14 April 2019).

Here Tebogo is identifying the fact that the mechanisation of production lines renders the labour of workers elsewhere in the process more and more important. The labour of workers in logistics is central to the production of surplus value for PFG because they form an essential component of what Marx (1990 [1867]: 644) calls the "collective labour" of the factory. Logistics workers at PFG ultimately ensure that the glass produced on the production lines reaches the point of exchange, which completes the labour process by turning it into a saleable commodity. The labour time that logistics workers invest in this process not only adds new value to the finished commodity, but it is also important to note that without such labour the value that is initially produced on the production lines cannot be realised.

It is interesting to note that the initial mechanisation of production lines in the early twentieth century resulted in the rise of mass production, which amplified the threat of crises of overproduction. This meant that manufacturing capital had to become increasingly concerned with the realisation of the surplus value that it creates. In other words, capital had to find more efficient ways to store, move and sell the commodities that it was producing in ever-larger quantities. The importance of what is now called logistics work inside the industrial workplace is, therefore, not

\footnotetext{
${ }^{2}$ The toyi-toyi is a form of protest dance that is widely used across Southern Africa during protests, strikes and political meetings. It is characterised by a high-kneed, foot-stomping dance in rhythm to protest songs.
} 
altogether new. The potential assumption that these workers are less important to capital because they are not located at "the point of production" would, therefore, be misplaced.

Indeed, the importance of the LSC workers was also well understood by NUMSA. The NUMSA regional secretary told permanent workers that

their strike won't be successful because LSC Masakhe employees were inside the factory and PFG will use them to do your job. There are LSC workers who have been trained to operate the line (Tebogo, PFG group interview, 14 May 2019).

LSC workers did eventually decide to down tools in solidarity and to join the strike. However, joining the strike did not further their own struggles to be permanent. This mirrors the experience of other labour broker workers who have similarly found their numeric and strategic importance used in furthering the struggles of permanent workers while their own demands are left aside (Englert and Runciman, 2019).

After three years, the workers began to organise themselves and began holding meetings in the nearby township of KwaThema. They also approached CWAO for assistance in taking up a section 198 case at the CCMA. However, in the process of preparing for arbitration, LSC workers found out that NUMSA had launched a section 198 case on their behalf at the Labour Court a few months earlier and without their knowledge. Rather than this being a welcome development and a sign that NUMSA was willing and able to take up their issues, conversely this heightened their suspicion of NUMSA; they saw it as a sign that the union was "blocking all [their] positive moves", possibly in the interests of management (Fieldnotes taken by Dor, PFG worker meeting, 14 April 2019).

The extreme levels of suspicion that labour broker workers direct towards the union leadership appear, in our analysis, to stem from the disjuncture between the workers' favourable perceptions of their own power to fight for and win their demands (an assessment which is based both on their willingness to struggle and in relation to the important role they play in the labour process), and the union bureaucracy's paternalistic approach of taking decisions on their behalf.

\section{Conclusion: Problematising the Core and Non-core}

The cases presented confirm that precarious workers are located at the very heart of production, and demonstrate capital's willingness to replace their old core workforce with precarious workers, wherever possible. As these case studies demonstrate, the amendments to section 198 of the LRA encouraged employers to restructure work in order to evade their responsibilities under the law through reclassifying large parts of their labour process as non-core functions, which they claim have been "outsourced" to "service providers". This has allowed them to continue to externalise the employment relationship with a majority of their workers on a permanent basis. At both Reckitt and PFG, management has narrowed the definition of its core functions to such an extreme extent that it only covers the work of machine operators on the production lines and other higher-paid supervisor or professional positions. Indeed, one of Reckitt's labour brokers captures the mood of employers perfectly when it says that "your core business is what you choose it to be" (Carrus, 2019: n.p.).

This complicates our understanding of core and non-core. While Von Holdt and Webster (2008) acknowledge that precarious workers can and do work at the core of production, in practice their original model and the subsequent elaborations of it have tended to reinforce an analysis that regards precarious workers as peripheral to production. In understanding the "core" we must also 
be alert to the changing nature of what capital chooses to define as their core business, especially in relation to the post-section 198 restructuring efforts that we have explored in this article. In light of this, it is no longer sufficient to demonstrate the growth in importance of precarious work by simply locating precarious workers at the core of a manufacturing company's labour process. This is, first, because capital is constantly shifting the goalposts in terms of what they choose to define as a core process and, second, because the mechanisation or automation of production lines constantly renders redundant those workers who would have traditionally been considered "core to production". So, while it is important to note that precarious workers are indeed found at the centre of production, it is also important to note that industrial capital relies on far fewer workers in the actual manufacturing of goods than it once did. The relative proportion of all sorts of auxiliary workers in industrial workplaces is inevitably greater than it would have been a few decades ago, and, as a result, the relative importance of these workers to the full functioning of factories has risen. In line with this, the case studies featured within this article demonstrate that precarious workers are central not only to production but, more importantly, they play a central role in both the creation and realisation of surplus value for manufacturing firms even when they are found in auxiliary positions away from the production lines.

The article has also documented how, under conditions of precarity, workers have attempted to organise to realise their rights to permanent work. The fragmented workplace makes it difficult for workers to even know their workplace, as illustrated by the incomplete knowledge of the labour process presented in this article. Furthermore, this fragmentation makes it difficult for workers to even agree on who their employer is or should be. Both cases illustrate examples where trade unions have attempted to organise precarious workers. At Reckitt the attempts to organise labour broker workers was thoroughly defeated by a mass dismissal, which has had damaging long-term consequences for the union's ability to organise. Despite this, workers continue to attempt to organise, embarking on strategies inside and parallel to trade unions, an experience that is reflected elsewhere (Englert and Runciman, 2019).

At PFG, NUMSA's approach to precarious workers was largely an instrumental one, using their numerical majority to further the demands of permanent workers. NUMSA's approach to organising brokered workers separately from permanents, as they have done elsewhere (see Englert and Runciman, 2019), has only served to entrench the workplace divide on which management's valorisation regime rests. This has fostered a deep suspicion of NUMSA's motives so that even when, in theory, it does begin to address the concerns of workers this is met with hostility. As at Reckitt, workers combine organising in unions with independent organising initiatives.

Our aim in this article has been to reflect the social realities of the terrain of struggle which precarious workers in the manufacturing sector face. In so doing, we have expanded our gaze beyond the traditional trade union form, as Atzeni (2021) advocates, to map the complex ways in which precarious workers organise inside, outside and in parallel to trade unions. This analysis has highlighted the multiple organising strategies that precarious workers are using in the current period, which involves joining trade unions while also maintaining independent organising efforts. This finding is mirrored among precarious workers across other sectors in South Africa (Englert and Runciman, 2019), and even among permanent workers, as Sinwell (2015) has documented among mineworkers in the Platinum Belt. The impetus to organise independently is not, as Pero (2019: 906) suggests, the result of "an a priori strong ideological indifference to mainstream unions" but a reflection of their negative experiences and exclusion from meaningful participation within them. The exclusion that precarious workers often experience within trade unions is underscored within our PFG case study.

What this article has sought to question, through its analysis of worker organising, is not how 
trade unions can be revitalised but how the broader labour movement can be revitalised, especially in light of the current structural challenges that exist thanks to decades of restructuring in the manufacturing industries. In addressing this question, as Atzeni (2021) argues, we cannot use trade unions as the only starting point. Instead, as precarious workers themselves are demonstrating, at this point in time trade unions are just one organisational strategy among others. To understand why this is the case, we have shown that it is necessary to take as a starting point the specific context in which workers labour and wage their immediate struggles - that is, the workplace. All debates on organising methods or practices (the content of organising) and organising models (the form of organisation) must necessarily be subsumed under an analysis of the changing nature of the workplace, as it is, of course, the immediate terrain on which worker organising takes place. By establishing the trade union form as the sole entry point for all labour studies we stand to miss the significance of the changes that have taken place in the manufacturing labour process and, as a result, we will be unable to appreciate the changing and diverse nature of the struggles that different groups of workers are currently fighting.

\section{References}

Atzeni, M. (2021) Workers' Organizations and the Fetishism of the Trade Union Form: Toward New Pathways for Research on the Labour Movement? Globalizations, 18(8): 1349-1362.

Barnes, T., K.S. Lal Das and S. Pratap (2015) Labour Contractors and Global Production Networks: The Case of India's Auto Supply Chain. The Journal of Development Studies, 51(4): 355-369.

Bischoff, C. and B. Tame (2017) Labour Aristocracy or Marginal Labour Elite? In Labour beyond Cosatu: Mapping the Rupture in South Africa's Labour Landscape, edited by A. Bezuidenhout and M. Tshoaedi. Johannesburg: Wits University Press.

Braverman, H. (1974) Labor and Monopoly Capital. New York and London: Monthly Review Press.

Brooks, C., S. Singh and S. Winslow (2017) Trainers' Guide: Secrets of a Successful Organiser. New York: Labour Notes.

Budlender, D. (2013) Private Employment Agencies in South Africa. Geneva: ILO.

Buhlungu, S. and E. Webster (2006) Work Restructuring and the Future of Labour in South Africa. In State of the Nation: South Africa 2005-2006, edited by S. Buhlungu, J. Daniel, R. Southall and J. Lutchman. Cape Town: HSRC Press.

Burawoy, M. (1982) Manufacturing Consent: Changes in the Labor Process under Monopoly Capitalism. Chicago, IL: University of Chicago Press.

Carrus (2019) Carrus Business Process Outsourcing an Alternative to Permanent Employment. http://www.carrus.co.za (accessed 12 August 2019).

Cassim, A. and D. Casale. (2018) How Large is the Wage Penalty in the Labour Broker Sector: Evidence for South Africa using Administrative Data. https://www.wider.unu.edu/publication/how-large-wage-penaltylabour-broker-sector (accessed 5 November 2018).

Constitutional Court (2018) Judgment: Assign Services (Pty) Limited v National Union of Metalworkers of South Africa and Others [2018] ZACC 22.

Constitutional Court (2020) Judgment: Victor and Others v Chep South Africa (Pty) Ltd and Others [2020] ZALAC 59 .

Dickinson, D. (2017) Contracting Out of the Constitution: Labour Brokers, Post Office Casual Workers and the Failure of South Africa's Industrial Relations Framework. Journal of Southern African Studies, 43(4):789-803. 
Dor, L. (2020) Precarious Workers and the Labour Process: A Multi-sited Case Study of Management Control and Worker Resistance. Unpublished Masters dissertation, University of Johannesburg, Johannesburg.

Edwards, R. (1979) Contested Terrain: The Transformation of the Workplace in the Twentieth Century. New York: Basic Books.

Englert, T. (2018) Precarious Workers, their Power and the Ways to Realise It: The Struggle of Heineken Labour Broker Workers. Unpublished Masters dissertation, University of the Witwatersrand, Johannesburg.

Englert, T. and C. Runciman (2019) Challenging Workplace Inequality: Precarious Workers’ Institutional and Associational Power in Gauteng, South Africa. Transformation: Critical Perspectives on Southern Africa, 101: 84-104.

Friedman, A. (1977) Industry and Labour: Class Struggle at Work and Monopoly Capitalism. London: Macmillan.

Gibson, N.G. (2006) Challenging Hegemony: Social Movements and the Quest for a New Humanism in Post-apartheid South Africa. Trenton, NJ: Africa World Press.

Kenny, B. and E. Webster (1998) Eroding the Core: Flexibility and the Re-segmentation of the South African Labour Market. Critical Sociology, 24(3): 216-243.

Marx, K. (1990 [1867]) Capital Volume 1. London: Penguin Books.

Moodie, T.D. and V. Ndatshe (1994) Going For Gold: Men, Mines, and Migration. Los Angeles, CA: University of California Press.

Parry, J. (2013) Company and Contract Labour in a Central Indian Steel Plant, Economy and Society, 42(3): 348-374.

Pero, D. (2019) Indie Unions, Organizing and Labour Renewal: Learning from Precarious Migrant Workers. Work, Employment and Society, 34: 900-918.

PFG Building Glass (2019) PFG's Services, Trade and Exports. https://pfg.co.za/technical-services (accessed 1 August 2019).

Reckitt Benckiser Group plc (2018) Annual Report and Financial Statements 2018. Slough, Berkshire: Reckitt Benckiser Group.

Rees, R. (2019) Becoming Permanent: Taking Section 198 Up. Johannesburg: NALEDI.

Ryan, E. (2019) Silica Gives the Magic of Glass. In Quarry Online. https://www.quarryonline.co.za Lindex.php/features/150-silica-gives-the-magic-of-glass (accessed 23 August 2019).

Sinwell, L. (2015) “AMCU by Day, Workers' Committee by Night”: Insurgent Trade Unionism at Anglo Platinum (Amplats) Mine, 2012-2014. Review of African Political Economy 24(146): 591-605.

Sitas, A. (1983) African Worker Responses on the East Rand to Changes in the Metal Industry. Unpublished Doctoral thesis, University of the Witwatersrand, Johannesburg.

Smit, S. (2018) Court Shows Employers Who’s Boss. Mail and Guardian, July 27. https://mg.co.za/article/ 2018-07-27-00-court-shows-employers-whos-boss (accessed 10 August 2020).

Theron, J. (2005) Employment is Not What It Used To Be: The Nature and Impact of Work Restructuring in South Africa. In Beyond the Apartheid Workplace. Studies in Transition, edited by E. Webster and K. von Holdt. Pietermaritzburg: University of KwaZulu-Natal Press.

Von Holdt, K. and E. Webster (2005) Work Restructuring and the Crisis of Reproduction: A Southern Perspective. In Beyond the Apartheid Workplace: Studies in Transition, edited by E. Webster and K. von Holdt. Pietermaritzburg: University of KwaZulu-Natal Press.

Von Holdt, K. and E. Webster (2008) Organising on the Periphery: New Sources of Power in the South African Workplace. Employee Relations, 30(4): 333-354.

Wardell, M. (1990) Labour and Labour Process. In Labour Process Theory, edited by D. Knights and H. Willmott. London: Macmillan. 
Webster, D. (2020) Ferrero Workers Challenge Zero Hours Contracts. Mail and Guardian, January 27. https://mg.co.za/article/2020-01-27-ferrero-workers-challenge-zero-hours-contracts (accessed 10 August 2020).

Webster, E. (1985) Cast in a Racial Mould: Labour Process and Trade Unionism in the Foundries. Johannesburg: Ravan Press.

Webster, E., A.O. Britwum and S. Bhowmik (2017) Crossing the Divide: Precarious Work and the Future of Labour. Pietermaritzburg: University of KwaZulu-Natal Press.

Webster, E. and T. Englert (2020) New Dawn or End of Labour? From South Africa's East Rand to Ekurhuleni. Globalizations, 17(2): 279-293.

Webster, E. and D. Francis (2018) The Reproduction of Inequality in Post-apartheid South Africa. Paper presented to a seminar at the Southern Centre for Inequality (SCIS), University of the Witwatersrand, 13 February 2018.

Webster, E. and D. Francis (2019) The Paradox of Inequality in South Africa - A Challenge from the Workplace. Transformation: Critical Perspectives on Southern Africa, 101: 11-35.

Zimbalist, A.S. (1979) Introduction. In Case Studies on the Labor Process, edited by A.S. Zimbalist. New York: Monthly Review Press.

\section{Interviews}

1. Eric (general worker), interview, 26 August 2019, Germiston. [Digital recording in possession of author.]

2. Eric and Siya, interview, 11 June 2019, Germiston. [Digital recording in possession of author.]

3. Alfred (crane operator), interview, 2 April 2019, Germiston. [Digital recording in possession of author.]

4. PFG group interview, 14 Mary 2019, Germiston. [Digital recording in possession of author.]

5. PFG worker meeting with CWAO, 14 April 2019, Germiston. [Notes in possession of author.]

\section{ACKNOWLEDGEMENTS}

The authors would like to thank all of the workers at PFG and Reckitt who participated in the research and generously gave their time and shared their insights. We also thank the Casual Workers Advice Office for their support for this research. The research was made possible by a grant from the National Research Foundation.

\section{BIOGRAPHICAL NOTES}

LYNFORD DOR is a researcher at the Centre for Social Change, University of Johannesburg. Prior to this, he was the Education and Media Officer at the Casual Workers Advice Office. [Email: lynforddor@gmail.com]

CARIN RunCIMAn is the Director of the Centre for Social Change and an Associate Professor in the Department of Sociology, University of Johannesburg. Her research specialises in workingclass politics and mobilisation in post-apartheid South Africa. [Email: crunciman@uj.ac.za] 